\title{
Safeguards for donors
}

\section{Clashing perspectives on the ethics of the donation of human eggs for research purposes are likely to complicate international collaboration - whether stem-cell researchers like it or not.}

V hat price a human egg? The question provokes a variety of emotions and responses. Some will argue that an egg has no monetary value when it is just one of those ovulated each month by billions of women and that perishes unfertilized. Others might contend that the same egg is priceless - because it could, if introduced to the correct sperm, form the seed of a new person. Others still will find it morally problematic even to pose the question, on the grounds that it treats human cells as merchandise.

But the question is being asked, nonetheless - indeed, it is at the forefront of a vigorous debate about whether and how much to pay women for donating their eggs for research (see page 606). Some biologists are keen to use fresh human eggs for the production of human embryonic stem cells. Yet they are anxious to distance themselves from the path taken by disgraced South Korean researcher Woo Suk Hwang, who lied about paying women for eggs and tainted the whole idea of oocyte donation.

In a Commentary in this week's issue, Insoo Hyun of Case Western Reserve University in Cleveland, Ohio, who chairs a task force exploring the issue at the International Society for Stem Cell Research, argues that women who donate eggs should be financially compensated for their time, discomfort and trouble (see page 629). Hyun argues that institutional review boards and other oversight bodies can select a level of remuneration that is enough to ensure that donors are compensated for their trouble, but not enough to blind them to the risks involved.

That will be an exquisitely fine line to draw. A sum that will be merely compensation for one woman could be enticement for another, poorer one. And in the real world, where questions over dinical research, informed consent and conflicts of interest have lately enjoyed a high profile, confidence in the ability of these review boards to ensure adequate oversight will not be universally shared.
The situation is further complicated by the health risks that may be posed by ovarian stimulation (see page 607). There are hints, but no definitive evidence, that the drugs used to stimulate the ovaries for both in vitro fertilization (IVF) and egg donation increase the long-term risks of cancer. How, then, can a fair level of compensation be set for risks that are essentially unknown?

One possible way forward lies in a practice called egg-sharing, in which women who are already considering or undergoing IVF are asked to contribute surplus eggs to research in return for treatment at reduced cost. The North East England Stem Cell Institute in Newcastle Upon Tyne, UK, will soon start offering this scheme. Proponents point out that, by working with donors who are using ovulation-stimulating drugs anyway, this avoids exposing otherwise healthy women to any risks associated with them. The idea does not, however, impress those who object on ethical grounds to any financial inducements to donors.

The International Society for Stem Cell Research is currently drafting guidelines on this

\section{"How can a fair level of compensation be set for risksthat are virtually unknown?"} issue. But they won't overrule local laws and regulations, the uneven application of which looks set to slow down stem-cell research. Researchers in nations that prohibit payment for eggs, for example, may find themselves unable to work on stem cells derived from eggs secured by collaborators elsewhere from paid donors.

In April 2005, the US National Academies issued guidelines stating that women who donate eggs for research should receive only direct expenses, such as travel to the clinic. If stem-cell researchers are to suggest that payments should be more extensive, they will have to make a more convincing case that adequate safeguards will be in place to protect donors' rights.

\section{Capturing carbon}

\section{Sequestration of greenhouse gases could play an} important role in capping emissions.

ए resh approaches to energy use and production are vital if seri- ous climate change is to be averted and developing countries are to attain the standards of living to which they aspire. However, the rich nations spend a deplorably low proportion of their research funds on energy - far less, in real terms, than they were spending 25 years ago.

The case for greater emphasis on energy research is overwhelming, and was made again last week by Martin Rees, president of Britain's Royal Society (see Science 313, 591; 2006). But sometimes research can get in the way of deployment. Scientists can always find further interesting questions, and research can become an end in itself. In some fields, there is a need, instead, for action. Energy conservation is the most obvious case. Carbon capture and storage - which offers the possibility of using fossil fuels without releasing carbon dioxide into the atmosphere (see page 620) - is another.

Bringing carbon sequestration onto a faster track requires more than scattered demonstration projects and a vague hope that prudent industries might voluntarily adopt it at some point in the future. The International Energy Agency predicts that 1,400 gigawatts of new, coal-fired generating capacity will be commissioned worldwide in the next 25 years. The United States has proposals for 153 coalfired plants under consideration, few of which are likely to be designed with carbon capture in mind. And every year, China builds coal-powered plants capable of generating a stunning 75 gigawatts 